Lea, D., (2015) Narrative Wreckage: Cancer and the Unfortunate Body in B.S. Johnson', English Studies, 96 (6), pp. 785-798.

DOI: https://dx.doi.org.10.1080/0013838X.2015.1051869

This document is the author's Accepted Manuscript.

License: https://creativecommons.org/licenses/by-nc-nd/4.0

Available from RADAR: https://radar.brookes.ac.uk/radar/items/d08d5a6a-7860-42a0-b523-807cd3a55544/1/

Copyright $(\subset$ and Moral Rights are retained by the author(s) and/ or other copyright owners unless otherwise waived in a license stated or linked to above. A copy can be downloaded for personal non-commercial research or study, without prior permission or charge. This item cannot be reproduced or quoted extensively from without first obtaining permission in writing from the copyright holder(s). The content must not be changed in any way or sold commercially in any format or medium without the formal permission of the copyright holders. 


\section{Narrative Wreckage: Cancer and the Unfortunate Body in B.S. Johnson}

\section{Daniel Lea ${ }^{1}$}

\section{Abstract:}

In Illness as Metaphor, Susan Sontag claims that cancer is the perfect metaphorical descriptor for late-capitalism's unbridled consumption and wild proliferation. Cancer is a disease she suggests that disdains order; it defies the reason of science, and in so doing, accurately reflects the decentred subject of contemporary philosophy and politics. The irrationality of the disease inhibits narrativisation, imbuing the stories we tell about it with an anxiety that often manifests itself in the use of metaphors of wars, battles, invasions and survivorship. In the realm of fiction, B.S. Johnson's experimental anti-novel The Unfortunates (1969) stands as one attempt to represent the arbitrariness of cancer and its ability to deconstruct the hermeneutic reliability of narrative. Famously published as a collection of twenty-seven independent sections which the novel details the stream of consciousness of its narrator as he meditates on the death from cancer of his close friend, Tony. Unable to make sense of this death in any linear or consequential manner, the text reflects in the manner (and limitations) of its construction not just the randomness of illness, but also the proliferation of empty stories that are produced to explain it. Through close examination of Johnson's representation of the male body in illness, this essay explores the impossibility of controlling meaning when it comes to the great unknown of cancer. It centrally address the obliquity with which the diseased and malfunctioning male body has been represented, and suggests that the narrative wreckage that constitutes Johnson's experiment is less a localised strategy and more a textual microcosm of the collective despair at the irresistible profusion of cancer.

\footnotetext{
${ }^{1}$ Daniel Lea is affiliated with the Department of English and Modern Languages, Oxford Brookes University, UK. Email: dlea@brookes.ac.uk
} 
Keywords: B.S. Johnson; The Unfortunates; cancer; male body; narratives of illness; cultural metastases

... to have great pain is to have certainty;

to hear that another person has pain is to have doubt. ${ }^{2}$

B.S. Johnson's The Unfortunates (1969) contains much pain and a great deal of the doubt that Elaine Scarry identifies as the common human response to the suffering of the other. What it lacks is certainty, and in particular the kind of certainty that allows its first-person narrator cogently to articulate his grief for his friend, Tony, who has died from cancer at the age of twenty-nine. The narrator struggles with the seemingly insuperable task of rationalising the emotional disorder of loss, but for all his grappling for meaning, the brute fact of mortality remains uncharted and irreducible. The pain of the other, in its unnegotiable alienness, stays incommunicable but reflects back on to the observer's experience of their own subjective coherence with all the force of its unheimlich incertitude. How to express in the fluidity of words the particularity of another's suffering haunts the narrative and the endeavours of the narrator, turning the truth of physical vulnerability manifest in a catalogue of symptoms into generalization and cliché. "The difficulty is to understand without generalization," the narrator ruminates, "In general, generalization is to lie, to tell lies." ${ }^{3}$ The duty of telling the "truth" of another's experience becomes hopelessly tangled in The Unfortunates with the ethical complications of telling one's own truth, or at least narrativizing it in such a way that it creates a truth-effect. The most celebrated feature of the novel's production attests to Johnson's scepticism towards the singularity of any truth, however solipsistic.

\footnotetext{
${ }^{2}$ Scarry, 7.

3 Johnson, Unfortunates, "Last", 6. In line with critical precedent in addressing The Unfortunates, references to the text's twenty-seven individual sections will be identified by a short précis of the opening line of the section under discussion followed by a page reference.
} 
The Unfortunates, almost universally referred to as the "book in a box", consists of twentyseven unbound sections, of which only two - the "First" and "Last" - are identified as requiring to be read in a specific order. The remaining sections are distinguished by individual icons and range in length from a single page to twelve pages. The loop of paper that holds the sections temporarily together encourages the reader to read these sections in a random order, the narrative thus generated being one of $1.551121 \times 10^{25}$ potential combinations. ${ }^{4}$ Unsurprisingly, the radical deconstructedness of this formal experimentalism has attracted its fair share of critical attention and has often seemed to overshadow the rather prosaic subject-matter of the text which concerns the journalist narrator's trip to a Midland city (identifiable as Nottingham) to cover a football match. The assignment returns the narrator not only to a place of his youth, but also to a conflicted and traumatic landscape of memories related to the life and death of Tony. Intuitive by construction and associative by development, The Unfortunates builds a collage of memory fragments that detail the gradual deterioration of Tony, the guilt the narrator feels for his emotional ambivalence towards his friend, and his desire to fulfil his promise to "get it all down." ${ }^{5}$ The aleatoric nature of the reading process, with its chronological haphazardness and ontological dissonance undermines certainty as a quality of our relationship with the other, proffering instead the contingent and the accidental as coordinates for connection. As Philip Tew has commented, "the dynamics of understanding are frequently non-literal, non-verbal" and the difficulty of expressing alterity in words cycles repeatedly through the text. ${ }^{6}$ For Scarry, this difficulty is multiplied with the consideration of another's suffering, for language fails in the face of pain's "unsharability": "Physical pain does not simply resist language but actively destroys it, bringing about an immediate reversion to a state anterior to language, to the sounds and cries a human being makes before language is learned." "Getting down" the experience of another's body in pain marks a crisis in the territory between subject, object and abject that throws certainty into disorder and obscenity. Pain "has no referential content.

\footnotetext{
${ }^{4}$ Kirby, 92.

5 Johnson, Unfortunates, "So he came to his parents", 5.

${ }^{6}$ Tew, Johnson: A Critical Reading, 41.

${ }^{7}$ Scarry, 4.
} 
It is not of or for anything" and thus resists objectification. ${ }^{8}$ Representing the pain of Tony's cancered body consequently becomes not only an exercise in self-negation for the narrator, but also an ethical failure to be true to his own word.

Criticism on The Unfortunates has tended to focus first and foremost on the formal challenges presented by Johnson, regarding Tony's cancer as a vehicle for Johnson's concern with the non-linearity of memory and memorialisation, rather than a focus of attention in itself. ${ }^{9}$ This essay is primarily interested in the cancer, and the ways in which it speaks in the narrative through its embodiment in Tony's pain, deterioration and death. The argument put forward will be that cancer represents a kind of unrepresentability that goes beyond the ineloquent suffering inherent in other illnesses; that the formal disorderliness of the novel with its multiplicity of readings reflects the excessive and proliferative growth of the cancer cell, and that the metaphor of cancer used by Johnson speaks to a late-twentieth-century anxiety over the healthiness of overabundant consumption, information and signification. Principally, however, it will address the cancered male body in all its horrifying, abject sublimity.

Cancer evokes a deep-seated, primeval terror. Though heart disease, strokes, diabetes and other diseases of affluence kill millions in Westernised countries, cancer casts a particularly black shadow that has yet to be dispersed by improved treatment regimens and increasing survival rates. Susan Sontag in IIIness as Metaphor and Jackie Stacey in Teratologies: A Cultural Study of Cancer have pointed out the very simple equation that underpins cancer's mythological staying-power: cancer $=$ death. ${ }^{10} \mathrm{~A}$ diagnosis of cancer initiates a set of shockwaves that enfolds the individual, those around them, their language, culture, and perceptions of the world within discourses of inevitable mortality that are both internally and externally situated. Sontag claims that a culture of lying to, and about cancer sufferers has reinforced the connection between the disease and death: "Cancer patients are lied to, not, just because the disease is (or is thought to be) a death sentence,

\footnotetext{
${ }^{8}$ Ibid., 5.

${ }^{9}$ As well as the material on Johnson referenced in this essay, see Levitt, "The Novels of B.S. Johnson"; Ryf, "Character and Imagination" and "Frontiers of Fiction."

${ }^{10}$ Sontag, Illness; Stacey.
} 
but because it is felt to be obscene - in the original meaning of that word: ill-omened, abominable, repugnant to the senses."11 $T$ This obscene quality derives in part from the truth that "cancer forces us to confront our lack of control over our own or others" death ... [it] points up our failure to explain and master much in our world", ${ }^{12}$ but also that cancers "cause languages to flee, they make it run along a witch's course, they place it endlessly in a state of disequilibrium, they cause it to bifurcate and to vary in each one of its terms, according to a ceaseless modulation." ${ }^{13}$ Part of the anarchic fear of cancer thus lies in its threat to destroy language, to decapitate our rationality in the face of the obscene and the abject, and despite its relative prevalence in Western societies (where current estimates suggest that one in three people will be directly affected at some point in their lives), ${ }^{14}$ it continues to be articulated through forms of shame-faced obliquity:

For the person diagnosed with cancer, a culture once saturated with information about how to avoid carcinogenic influences is transformed into one which is unable even to name the disease. We read everywhere of cancer's increasing prevalence and yet are deeply shocked when it does not pass us by. Cancer has a ubiquitous presence in everyday culture and yet the person with cancer is nevertheless confronted by a striking silence that reminds them they have entered stigmatised territory. ${ }^{15}$

The silence that surrounds cancer for Stacey emerges not from ignorance of cause and effect, but from a certain dumbfoundedness about how to describe the experience of alterity that immediately envelops the patient, making them "an entity beyond culture."16 The otherness that overcomes the sufferer derives in part from the embedded cultural suspicion of cancer's spatial

\footnotetext{
${ }^{11}$ Sontag, Illness, 9.

12 Kleinman, 20.

${ }^{13}$ Gilles Deleuze, quoted in Doel, 62.

${ }^{14}$ http://www.macmillan.org.uk/Cancerinformation/Aboutcancer/Whogetscancer.aspx\#.UH_Qcm_A-to (accessed 18 October 2012).

${ }^{15}$ Stacey, 70.

${ }^{16}$ Helman, 133.
} 
domain both within and without the body. From where cancer "comes" (in a metaphysical rather than a biomedical sense) contributes not inconsiderably to its terrifying spectre because it is simultaneously a disease of the inside and outside. Though frequently represented in popular discourse as a rampaging, voracious malignancy of the interior constitution, it is paradoxically also as frequently understood as a threat from the exterior world: "Cancer is ... freighted with meanings of the risks of invisible pollutants, such as ionizing radiation and even the chemical constituents of the very foods we eat ... [which] meld fears of contamination with the great modern threat of man-made catastrophes that poison the environment with toxic wastes." ${ }^{17}$ The uncertain provenance of cancer in the collective imagination highlights anxieties about the relationships between self and other, self and society, self and nature and self and technology, and the degrees to which they are internalised as embodied phenomena. The permeability of the body's defences - both psychological and physical - is directly called into question by cancer, and the involuntary blending of the "clean" and "unclean" (to use Julia Kristeva's terms) ${ }^{18}$ generates a crisis of the subject/object nexus that can best be described as abject. Jackie Stacey writes very eloquently of this unsettling fusion and is worth quoting at length:

The malignant cell of the cancer tumour is not an invader, an outsider, like a virus or a bacterium; rather it is produced by the body, it is of the body, and yet it is a threat to the body. Neither self nor other, it is both the same as and different from its host. It is misrecognised as one of the body's normal cells, but it is a deviant cell in innocent disguise. ... The cancer cell is just a self-serving replicant with no duties. It should be an expelled object, but it remains part of the system, travelling incognito. Its facility for self-replication brings it more allies until they outnumber the cells of the organs which house them. The tumour which these rogue cells come to form is part of the body and yet separate from it. It is produced by bodily matter but its redundancy can kill. When it takes hold it can enlarge

\footnotetext{
${ }^{17}$ Kleinman, 20.

${ }^{18}$ Kristeva.
} 
organs and protrude from the body. It can even transgress bodily boundaries and break through the skin, bringing the inside to the outside. ... It impersonates the subject long enough to establish the power of its real difference, often until it can overpower its host body. ${ }^{19}$

The truly unsettling aspect of cancer is its stealthy, almost sly colonisation of the body, though such a description falls into the trap of anthropomorphizing as evil and self-conscious an indiscriminating bodily process in just the way that Sontag warns against in Illness as Metaphor. Cancer is stigmatised because it jeopardises our mind/body integer in the way that a condition such as a heart attack does not: "Cardiac disease implies a weakness, trouble, failure that is mechanical; there is no disgrace, nothing of the taboo that ... surrounds those who have cancer. ${ }^{\prime 20}$ To have cancer is to have a disease with a moral dimension, a failure of character rather than simple cellular dysfunction, for cancer is "the self at war with the self." ${ }^{\prime 21}$ This understanding of a pathological condition as producing a selfalienating effect allied to a public discourse of fear and anxiety enables us to locate Johnson's disquiet in the context of modernity's ambivalence about the body's ability to self-transcend.

Cancer, as Sontag shows, has long outreached its biological limits to become a metaphor for social dysfunction - consider the attribution of the cliché "a cancer on society" to describe any number of undesirable social contributions - but this significatory expansiveness became particularly prevalent in the second half of the twentieth century, finding fertile ground in philosophical accounts of the postmodern condition. The specific pathological narrative of cancer, with its focus on the excessive and unregulated proliferation of identical cells, lends itself effectively to an understanding of advanced capitalism which, in Sontag's words:

\footnotetext{
${ }^{19}$ Stacey, 77-78.

${ }^{20}$ Sontag, Illness, 9.

${ }^{21}$ Stacey, 62, author's emphasis.
} 
requires expansion, speculation, the creation of new needs (the problem of satisfaction and dissatisfaction); buying on credit; mobility - an economy that depends on the irrational indulgence of desire. ${ }^{22}$

As a silent, often symptomless corruptor of healthy tissue, cancer can quite easily be co-opted into such a Leftist critique of over-production and over-consumption, but the very way in which cancer cells spread has resulted in readings of the disease that outstrip the political. What Marcus Doel calls the "cancerous geography" of poststructuralism emphasises the un-orderly, non-hierarchical, rhizomatic understanding of knowledge stripped of metanarrative and totalizing principles. ${ }^{23}$ The irrational, excessive replication of homogenous units of information in a patternless orgy of metastasis characterizes both disease and the spatial imperialism of the age of the simulacrum. Digital information spreads not through authoritarian channels but along Deleuzian lines of flight, and with such promiscuous avidity that they create what Jean Baudrillard calls: "an excrescential society whose development is uncontrollable, occurring without regard for self-definition, where the accumulation of effects goes hand in hand with the disappearance of causes." ${ }^{24}$ Baudrillard characterizes advanced capitalism as a system "governed not so much by growth as by growths", ${ }^{25}$ and utilises cancerous proliferation as a metaphor for the system's excessive over-productivity of the identical in the arena of aesthetics:

Behind the whole convulsive movement of modern art lies a kind of inertia, something that can no longer transcend itself and has therefore turned in upon itself, merely repeating itself at a faster and faster rate. On the one hand, then, a stasis of the living form of art, and at the

\footnotetext{
${ }^{22}$ Sontag, Illness, 64-65.

${ }^{23}$ Doel, 56.

${ }^{24}$ Baudrillard, 31.

${ }^{25}$ Ibid., 31.
} 
same time a proliferative tendency, wild hyperbole, and endless variations on all earlier forms..."26

This dual tendency towards inertia and proliferation can inform our reading of The Unfortunates for it perfectly articulates the problem of randomness within a fixed structure that has so troubled the novel's critics. While for Andrew Gibson the "heterogenous practice" and broken regularities of the text destabilize the relationship between singularity and multiplicity, ${ }^{27}$ others, like Patrick Parrinder, and Bernard Bergonzi, question the truly aleatoric nature of the reader's decision-making. ${ }^{28}$ Alan Kirby believes that the "multilinear form, and internal non-sequentiality" are "part of a whole", 29 while Philip Tew believes that the jumbling of sections results in a failure to "accumulate the same suspense or tragic impulse" as a conventionally paginated novel. ${ }^{30}$ Whatever the diegetic pros and cons of Johnson's experiment, the proliferation of reading-orders can be seen to effect a dynamic of difference in sameness that is metaphorically comparable to the work of the cancer cell. ${ }^{31}$ Within a framework of replication (the text of each section remains the same), numerous potential readings will occur. These "'rampant cells' inside a coffin-like box" suggest comparable readings of the body of the text and the bodies in the text, and focus attention less on the defensively dilatory and associative waywardness of the function of memory, and more on the embodied pain of the cancer sufferer. $^{32}$

Tony's broken and inutile body, tortured by its own cellular determinism, makes its entrance on the opening page of the "First" section, establishing the kind of grotesque jolt of misrecognition that will characterise its demise through the remainder of the novel:

\footnotetext{
${ }^{26}$ Ibid., 15.

${ }^{27}$ Gibson, 94.

${ }^{28}$ Parrinder, 127; Bergonzi, 29-30.

${ }^{29}$ Kirby, 92.

${ }^{30}$ Tew, Johnson: A Critical Reading, 40.

${ }^{31}$ The consonance between the structural and thematic concern with cancerous proliferation was indicated by the box-art of the first edition which showed a purple-hued close-up of cancer cells. This original design was not replicated in the 1999 re-publication of the novel by Picador, dislocating, to some extent, the physical object-status of Johnson's work from its dominant imaginative context.

32 Gibson, 95.
} 
Tony. His cheeks sallowed and collapsed round the insinuated bones, the gums shrivelled, was it, or shrunken, his teeth now standing free of each other in the unnatural half-yawn of his mouth, yes, the mouth that had been so full-fleshed, the whole face, too, now collapsed, derelict, the thick-framed glasses the only constant, the mouth held open as in a controlled scream, but no sound, the head moving only slightly, the white dried and sticky saliva, the last secretions of those harassed glands, cauterized into deficiency, his mouth closing only when he took water from a glass by his bed, that double bed, in his parents' house, bungalow, water or lemon he had to take frequently, because of what the treatment had done to his saliva glands, how it had finished them. $\quad \mathrm{H} \mathrm{i} \mathrm{m}^{33}$

This is a profoundly alienating image which constructs - or rather deconstructs - Tony through a number of objectifying tropes. The gaze of the narrator focuses primarily on the damage the disease - and, in the case the of his destroyed saliva glands, the treatment - have wrought, isolating individual areas of the face for horrified attention in a way which never allows Tony to cohere as a whole. The eyes, the teeth, the cheeks, the glands transform him into the aggregate of the malfunctions through which he is metonymically inscribed. ${ }^{34}$ That objectification intensifies in the tortured silent scream that so readily recalls the nameless agony of Edvard Munch's painting, and in the viscous mucosal "secretion" that resonates so inhumanly. The narrator's disconcerted state of mind at the memory is discernible in his vacillation about the "shrivelled" or "shrunken" condition of the gums suggesting a grappling for the solidity of language to describe something unnatural. Tony is thus transformed into a self-alienated bodily deficiency, devoid of agency or, crucially, selfexpression. Though there is a very clear focus on the mouth here, it is only as a conduit for the

\footnotetext{
${ }^{33}$ Johnson, Unfortunates, "First", 1.

${ }^{34}$ Johnson returned to this descriptive fragmentation in his 1973 novel, Christie Malry's Own Double Entry, where he describes the cancered Christie's body in a similar fashion: "His average eyes appeared shrunken, ringed with yellow-brown; his average cheeks had sunk, too. The general feeling about Christie now is one of sinking. ... So that the whole face seemed like a caricature of its earlier self, the mouth assumed an unnatural rictus, the skin became tauter and greyer, the lines standing out more whitely." Johnson, Christie Malry, 183.
} 
unspeakable pain and degradation of Tony's mortality, the sips of water he takes emphasising the lack of control he has over his speech faculties. Like his saliva glands, Tony is "finished" as a selfdetermining subject, and the narrator stresses this throughout by attending to the simple architecture of the bones and teeth rather than the character they convey. Tony is "derelict", like a ruined building, a thing of mere physical matter, his suffering incommunicable and impossible to understand.

This architectural metaphor appears again in the description of Tony's newly sown lawn or "earth it appeared as, just then, with lines of some sort, what were they? Not turves. Perhaps earth, just to cover the builders' rubble. ${ }^{\prime 35}$ The thin covering of earth that masks the detritus of the building process recalls the papery skin housing the collection of bones, barely sufficient to conceal the interior mechanisms that are so of the world of things, but so little of the individual. This portrayal of a deanimated interior of material cast-off, housed within a shell of spectral vitality assists in the process of reification through which Tony is transformed into a series of malfunctioning operations. This is frequently reinforced by his depiction through machinic analogies such as in the following from the "First" section:

... he had a great mind for [ ...] detail, it crowded his mind like documents in the Public Records Office, there, a good image, perhaps easy, but it was even something like as efficient, tidy, his mind, not as mine is, random, the circuit-breakers falling at hazard, tripped equally by association and non-association, repetition, while from him it flowed regularly, pointedly phrased, constantly, at a high constant, knowledge, learning, information, perhaps slowly, some, but how he embraced conversation, think of an image, no. ${ }^{36}$

Here, Tony's mental acuity is described in terms of its efficiency. Likened to a flow of electrical energy, he is constant and unbroken, a human device for processing, storing and transmitting

\footnotetext{
${ }^{35}$ Johnson, Unfortunates, "Then they had moved to a house", 4.

${ }^{36}$ Ibid., "First", 3.
} 
information in contrast to the circuit-broken associative randomness of the narrator. The potency of this indivertible flow needs to be contrasted with the stasis (indeed metastasis) of Tony's rictus; its lack of movement reiterating the atrophied processes caused by the cancer. Elsewhere, the narrator bemoans the "useless, pointless" nature of the death, once again emphasising the "use-lessness" of the body that fails to function efficiently. The cancered body cannot be used, it is no longer part of a functioning system and this absence from any economy of utility equally places it outside the domain of the explicable and the symbolic.

Tony's reduction to a conglomeration of non-functioning objective parts highlights the distinction that Johnson makes between the physical and non-physical realms. Cancer pushes its sufferer towards the borderline between subjectivity and objectivity, consigning her/him to a state of indistinction and this manifests itself in The Unfortunates in a narrative dynamic in which the narrator's genuine desire to commemorate the vivacity of his friendship with Tony, is resisted by his fear at the deracination that he witnesses the cancer producing. Throughout the text, his memory of Tony's deterioration is counterpointed by contemplations of the fragility of the human being in a world of objects. The Unfortunates is written in a sombre imagistic palette, in which the griminess and decay of the urban setting correspond to the tonal sense of distress and disorderliness. The physical surroundings of the city are expressed in shades of yellow, beige, dark reds, brown and creams, and draw attention to their depressed weightiness:

Cast parapet, pierced roundel design, the canal oiling its way under, under, and the great letters on the end wall of a warehouse BRITISH WATERWAYS, weathered, flaking, the midland red brick sound, it appears, the red strong enough to come through that amount of blackening, of discoloration ... ${ }^{37}$

\footnotetext{
${ }^{37}$ Ibid., "Cast parapet, pierced roundel design", 1.
} 
This kind of bleakness predominates without becoming a pathetic fallacy for the narrator's mental turmoil. Instead the quiddity of the object environment stands in contrast to the insubstantiality of the organic world of the human. The cream walls of pubs may be stained with cigarette smoke, the plywood tables veiled by faded damask cloths, but they represent not just endurance, but also a form of honest impoverishment: "the buildings proclaim that they are cheapjacks, charlatans, who might as if pack their bags overnight and leave, because in the buildings they would be leaving behind them the very minimum that could possibly be left, which would, which does, corrode, disintegrate, rot to pieces every few years." ${ }^{38}$ Yet, the "rejectamenta, the offthrown" of the human process retain a presence that is painfully contrasted by the absence of the human itself. ${ }^{39}$ At one point the narrator rails against the obscene vulnerability of a young girl with her arm in a sling, ${ }^{40}$ and, while purchasing ham, spirals into an involved consonance between meat and the wasting of human flesh. ${ }^{41}$ In fact the wasted (in every sense) body of Tony becomes a point of obsessive return for the narrator as he tries to rationalise the precariousness of the grip that the human being has on the material world.

The root, the value, and the purpose of that waste defy the narrator's need to shape order from the chaos, and he is left in a state of abject uncertainty about why and from where the cancer has emerged. In describing it, Johnson falls back upon the contradictory paradigms of inner and outer malignancy that were addressed earlier. The disease both is, and is not, of Tony; a morbidly cultivated means of self-destruction and an invasive, rampaging alien. The tumour itself is embodied and maliciously active - "its feelers or fingers or tentacles had grasped right around the collarbone" ${ }^{\prime 2}$ - while the "explosive, runaway, zealous, monstrous" cells that comprise it are equally energetic. ${ }^{43}$ The same parasitical external force eats up the land on the south coast where "new

\footnotetext{
${ }^{38}$ Ibid., "Time! It's after two!", 5-6.

39 Ibid., "For recuperation, after the first treatment", 4.

40 Ibid., "Here comes the main course", 1.

${ }^{41}$ Ibid., "The poky lane by a blackened sandstone church", 2-4.

${ }^{42}$ Ibid., "Just as it seemed things were going his way", 5.

${ }^{43}$ Ibid., "Just as it seemed things were going his way", 8.
} 
bungalows spread[...] cankerously over the cliffs." ${ }^{\prime 4}$ Yet, for all its invasive and frightening alterity, the cancer is also part not only of Tony's body, but also of his identity. At one point the narrator is forced to question the precise moment of the disease's inception, and ties it not to a random instance of cellular mutation, but to a form of existential waning on Tony's part: "did he in that moment, under that duress, decide he did not want to live, did something inside him decide, some organism, was something set in motion, irrevocably, irremediable?" ${ }^{45}$ Cancer, as a self-triggered desire to obliterate the self, has, as Sontag's IIIness and Metaphor details, long been associated with a type of melancholic and introspective character, and the narrator rehearses this stereotype in his attribution of blame to Tony for "allowing" the disease to manifest his inner conflict:

... it made me impatient ... and the object of such impatience, anger even, could only be Tony himself, the bearer of the disease, not the disease itself, as for the deity, ha! That this thing could just come from nowhere, from inside himself, of his old self, to attack him, to put his self in danger, I still do not understand. Perhaps there is nothing to be understood, perhaps understanding is simply not to be found, is not applicable to such a thing. But it is hard, hard, not to try to understand, even for me, who accept that all is nothing, that sense does not exist. ${ }^{46}$

Repeatedly, the narrator is brought face to face with his lack of understanding and his inability to contain the complicated nexus of emotions surrounding Tony's suffering, his own guilt and anger, his bitter regrets about a failed relationship, and his sense of physical vulnerability in a world of seemingly pitiless things, within a rationalism that can produce a single, palliative explanation. It is for this reason perhaps that he focuses so resolutely on Tony's voice. In it he sees hope for the transcendence of the material body, but this optimism makes its eventual failure doubly

\footnotetext{
${ }^{44}$ Ibid., "For recuperation, after the first treatment", 1.

${ }^{45}$ Ibid., "Just as it seemed things were going his way", 3.

${ }^{46}$ Ibid., "For recuperation, after the first treatment", 2.
} 
defeating. As "confidant, man of letters, adviser on novels, fellow poetry editor, wit, thinker and critic", Tony is defined by words, and by their ability to structure chaos into knowable, transmissible shapes. ${ }^{47}$ His relationship with the narrator is forged on their mutual passion for words - "the systole and diastole of informed conversation"- and thus the destruction of his voice undermines the very co-ordinates of their friendship, compelling the narrator to speak for them as a means of substantiating his own affective aliveness. ${ }^{48}$ As the disease takes its course, Tony is reduced not just to a collection of symptomalogical depredations, but also to grammatical disjunction:

His breathing, too, was affected, there were now great pauses in his conversation as he sighed to the limit of his lungs, unnatural pauses, unsyntactical, which gave his words curious emphases and dramatizations, bathos, together with those other pauses when he had to take a drink to moisten his mouth, manually to perform the saliva glands' function. ${ }^{49}$

The body, as a model of efficiency and use, becomes decreasingly capable of operating as a vehicle for self-enunciation; it is literally drying up. The pivot word here is "unsyntactical" which functions as potent descriptor for Tony's demise because it reinforces the idea of order disrupted. The syntax of a sentence relies upon the grammatical and logical distribution of elements within a framework of hermeneutics, but the cancer has the excessive and disordered pattern of a linguistic chaos that renders any organisation meaningless. We are returned at this point to Elaine Scarry's observation that pain brings about a reversion to "a state anterior to language", a Kristevan semiotic indistinction that traps the sufferer in the abject condition between material inanimation and self-fashioned subjectivity. "Disease is what speaks through the body ... a form of self-expression" and certainly Tony is not silent in his abjection, but he is increasingly spoken for, firstly by the brute signs of his

\footnotetext{
${ }^{47}$ Tew, Johnson: A Critical Reading, 41.

48 Johnson, Unfortunates, "That was the first time", 4.

49 Ibid., "Then they had moved to a house", 3.
} 
pained body, and subsequently by the narrator's promise to "get it all down." ${ }^{150}$ Arthur Frank writes that the "issue of telling stories about illness is to give voice to the body, so that the changed body can become once again familiar in these stories", ${ }^{51}$ but as is clear from the narrator's anxiety, there is no reclaiming of Tony's body from self-alienation:

... he himself wanted to be taken out of that now alien body, which was not himself, which was no longer under his control, the cells multiplying without reference to his will, destroying him and themselves. ${ }^{52}$

The narrator's horror at having "no control over the rampant cells either" determines him to exert the only means of ordering available to him, the "getting it down" that pins the experience of pain in the shape of words. In doing so, however, he privileges his own self-recuperative project over his duty to recognise the suffering of another, for in filling the space of the decaying body/voice with something substantial he is removing from Tony the right of his own bodily inarticulacy. If the pain of the other is anterior to language, then what the narrator effectively resolves is to metaphorize the non-metaphorical, to provide meaning for the abject, rather than allowing it to stand in the fullness of its own unspeakability. The horror of Tony's decay cannot be allowed to stand as a statement of the vulnerability of the human being, it must be spoken for by language. He is thus robbed of his own integrity as a vocal agent, just as that integrity is also robbed of him physically. His dry mouth encapsulates metonymically the withering of the subjective voice and the condition of non-being into which illness turns human meat, but the living's compulsive need for order and meaning ensures that his disintegration cannot remain eloquently silent.

Yet the compulsion to commemorate coincides for the narrator with the impossibility of articulating the experience of the other without generalization. As he shapes his report of the

\footnotetext{
${ }^{50}$ Sontag, Illness, 45.

${ }^{51}$ Frank, 2.

52 Johnson, Unfortunates, "Sometime that summer", 1.
} 
football match he is watching, he collides with the fundamental inappropriateness of language for describing the perceptual world:

Does this bloody reporting affect, destroy even, my own interest in language, sometimes I feel I have mislaid perhaps, not lost, something through this reporting, using under the pressure of deadlines the words which first come into my head, which is not good, relying on the chance of real words which may come in only the two hours of a match and the writing about it, oh what the hell ... ${ }^{53}$

The narrator's frustration with "how the clichés well up" ${ }^{54}$ to displace any profound appreciation of existence recalls Philip Tew's point that "language cannot assert its sovereignty over nature by which it is constrained; language conditions us to expect a framework that is confounded by the simple process of physical decay which we place outside of our experience, but which defines its form. ${ }^{\prime \prime 5}$ Johnson's struggle to determine a language of identification with Tony fails repeatedly because "the mind has fuses" which undermine the processes of representation and, more crucially, of memory. ${ }^{56}$ In Regarding the Pain of Others, Sontag claims that "too much remembering ... embitters. To make peace is to forget. To reconcile, it is necessary that memory be faulty and limited", and it is clear that the narrator's attempts to ascribe Tony's demise to a meaningful framework are deleterious to his own mental well-being: $:^{57}$

I sentimentalize again, the past is always to be sentimentalized, inevitably everything about him I see now in the light of what happened later, his slow disintegration, his death. The

\footnotetext{
53 Ibid, "The pitch worn, the worn patches", 7.

54 Ibid., "The pitch worn, the worn patches", 3.

${ }^{55}$ Tew, "(Re)-Acknowledging", 42.

56 Johnson, Unfortunates, "Then they had moved to a house", 5.

${ }^{57}$ Sontag, Regarding, 103.
} 
waves of the past batter, at the sea defences of my sandy sanity, need to be safely pictured, still, romanticized, prettified. ${ }^{58}$

That this prettifying can only ever be temporary and insufficient is indicated by his lament in the final section that "I just feel the pain, the pain." ${ }^{59}$ The horror of the cancer's deracinating action is continuously revivified by the act of memorialisation, preserving it in all its terror and abject fearfulness without the reconciling mechanism of amnesia. Drawing it again and again into focus, allows not a working through - as Freudian theories of trauma would suggest - but a repetitious and grim acknowledgement of the sublime dissolution of the relationship between one human subject and another.

To regard a human being with whom one identifies, and fail to recognise them as anything other than an object, is foundationally disconcerting intersubjectively, and to the subject's own psychological constitution. For Jacques Lacan this crisis is dictated by the force of the gaze which is always two-directional and always pre-exists the subject. In other words, as well as observing, the seer is constantly under observation by the object gaze, and that gaze is in, and of, the world before the subject, and regards her/him from all sides.$^{60}$ The power that accrues to observation is thus met and challenged by that which is outside the viewer's control. In the narrator's case the gaze that is returned is not that of Tony as friend, colleague and mentor, but the malign, disempowering gaze of the cancer and, beyond that, the abject retreat from subjectivity, language and reason that it represents. The Lacanian gaze fixes the observer with a return order to understand something that is beyond itself and beyond the remit of representation, and in the face of this demand, subjectivity recoils. It is thus evident that the threat presented by Tony's decline and death is restricted neither to the ethics of commemoration, nor the dynamics of language, but encompasses the fears of selfmisrecognition, dissolution and objectification that constitute the human condition. Tony's cancer

\footnotetext{
58 Johnson, Unfortunates, "I had a lovely flat then", 2.

59 Ibid., "Last", 4.

${ }^{60}$ Lacan.
} 
may present The Unfortunates's narrator with a crisis of ordering the emotional jetsam of the past, but more potently it throws into relief the tenuousness of his own self-making.

For the bearer of cancer, the pain that is so difficult to enunciate in words - and yet so easy to display in litanies of vile bodily symptoms - emerges from a complicated interleaving of physical, psychological, emotional, cultural, discursive, technological and biomedical crises that assert her/his place in the borderland between being and non-being. That this liminality maps so effectively onto the discourses of order and disorder that dominate late-modernity accounts, to some degree, for the continued psychosocial power of the cancer metaphor in an age where biomedicine has dramatically improved the effectiveness of treatments. What is at stake in the use of cancer as a metaphor today is less its direct association with death and more the disease's ability to disrupt systems and to confuse the co-ordinates of order that underpin contemporary ideas of efficiency. Though for Johnson in the late 1960s the resonance of cancer was more clearly, terrifyingly, terminal, the concerns of The Unfortunates, as much as its formal presentation, reveal comparable anxieties about disorder, dysfunction and determinism on the scale of the metaphysical as well as the physical. As Marcus Doel has claimed, "modernity is ambivalent: its regimes of ordering and disordering are of a piece. Order is not given; it must be made. To that extent, the fabrication of order is simultaneously the fabrication of disorder.." ${ }^{11}$ Reading Johnson's aleatoric experiment in the early twenty-first century thus reveals not just the arbitrariness of order, but also its familial consanguinity with the disorderly process of modernity.

\section{Bibliography:}

Baudrillard, Jean. The Transparency of Evil: Essays on Extreme Phenomena. Trans. James Benedict. London, New York: Verso, 1993.

Bergonzi, Bernard. The Situation of the Novel. London: Macmillan, 1979.

\footnotetext{
${ }^{61}$ Doel, 65.
} 
Doel, Marcus. Poststructuralist Geographies: The Diabolical Art of Spatial Science. Edinburgh: Edinburgh University Press, 1999.

Frank, Arthur W. The Wounded Storyteller: Body, Illness, and Ethics. Chicago; London: The University of Chicago Press, 1995.

Gibson, Andrew. Postmodernity, Ethics and the Novel. London: Routledge, 1999.

Helman, Cecil G. Culture, Health and IIIness. $5^{\text {th }}$ Edition. London: Hodder Arnold, 2007.

http://www.macmillan.org.uk/Cancerinformation/Aboutcancer/Whogetscancer.aspx\#.UH_Qcm_Ato (accessed 18 October 2012).

Johnson, B.S. Christie Malry's Own Double Entry. Harmondsworth: Penguin, 1984.

Johnson, B.S. The Unfortunates. London: Picador, 1999.

Kirby, Alan. Digimodernism: How New Technologies Dismantle the Postmodern and Reconfigure Our Culture. London: Continuum, 2009.

Kleinman, Arthur. The Illness Narratives: Suffering, Healing, and the Human Condition. New York: Basic Books, 1988.

Kristeva, Julia. Powers of Horror: An Essay on Abjection. New York: Columbia University Press, 1984. Lacan, Jacques. The Four Fundamental Concepts of Psycho-Analysis. Edited by Jacques-Alain Miller. Trans. Alan Sheridan. London: The Hogarth Press, 1977.

Levitt, Morton P. "The Novels of B.S. Johnson: Against the War Against Joyce." Modern Fiction Studies, 27, no.4 (1981): 571-586.

Parrinder, Patrick. The Failure of Theory: Essays on Criticism and Contemporary Fiction. Brighton: Harvester Press, 1987.

Ryf, Robert. "Character and Imagination in the Experimental Novel." Modern Fiction Studies, 20, no.3 (1974): 317-327.

--- "B.S. Johnson and the Frontiers of Fiction", Critique: Studies in Modern Fiction, 19, no.1 (1977): $58-74$ 
Scarry, Elaine. The Body in Pain: The Making and Unmaking of the World. New York; Oxford: Oxford University Press, 1985.

Sontag, Susan. Illness as Metaphor and AIDS and its Metaphors. London: Penguin, 1991.

--- Regarding the Pain of Others. London: Penguin, 2004.

Stacey, Jackie. Teratologies: A Cultural Study of Cancer. London and New York: Routledge, 1997.

Tew, Philip. B.S. Johnson: A Critical Reading. Manchester: Manchester University Press, 2001.

--- “(Re)-Acknowledging B.S. Johnsons Radical Realism, Or Re-Publishing The Unfortunates." Critical Survey, 13, no 1 (2001): 37-62. 